Autorzy tego wydawnictwa, zdając sobie sprawę z ogromnej wartości dokonań Towarzystwa Jezusowego na polu oświaty i wychowania, zapraszają do lektury wszystkich tych, którzy pragną realizować wizję św. Ignacego, kontynuować szlachetną tradycję, korzystać $\mathrm{z}$ bezcennych dokonań zakonu, a także przystosowywać model pedagogiki ignacjańskiej do obecnych czasów i torować jej drogę na przyszłość.

Joanna Falkowska

Karol Poznański, Wybrane zagadnienia $z$ historii wychowania. $C z$. 2, Warszawa 2006, Wydawnictwo Akademii Pedagogiki Specjalnej im. Marii Grzegorzewskiej w Warszawie, ss. 247

W ostatnich latach pojawiło się kilka nowych wydawnictw podręcznikowych do historii wychowania. Są wśród nich zarówno opracowania o charakterze syntez, jak i zarysów czy skryptów. Warto wśród nich wymienić Zarys historii wychowania Kaliny Bartnickiej i Ireny Szybiak ${ }^{1}$ oraz wydany w 2004 r., nakładem wydawnictwa WAM w Krakowie, podręcznik akademicki Historia wychowania. Do Wielkiej Rewolucji Francuskiej autorstwa Stanisława Litaka, uzupełniony w rok później tomem II pt. Historia wychowania. Wiek XIX $i$ XX, którego opracowania podjęli się Jan Draus i Ryszard Terlecki. Rok 2006 przyniósł wznowienie podręczników Stefana Możdżenia ${ }^{2}$ oraz dwa nowe opracowania pomocnicze - Historię wychowania. Skrypt dla studentów pedagogiki pod redakcją Danuty Dryndy ${ }^{3}$ oraz Wybrane zagadnienia z historii wychowania, cz. II opracowane przez Karola Poznańskiego. Ostatnia z wymienionych publikacji stanowi kontynuację wydanych w 2001 r., również przez Wydawnictwo Akademii Pedagogiki Specjalnej im. Marii Grzegorzewskiej w Warszawie, Wybranych zagadnien z historii wychowania cz. 1, autorstwa Hanny Markiewiczowej. Część I objęła okres od starożytności do reformacji i kontrreformacji, natomiast Karol Poznański w swojej książce uwzględnił dzieje wychowania od czasów nowożytnych do początków wieku XX (okres II Rzeczypospolitej).

Profesor Karol Poznański ukończył studia pedagogiczne na Katolickim Uniwersytecie Lubelskim, gdzie pod wpływem i opieką naukową prof. Jana Dobrzańskiego, napisał pracę magisterską i doktorską $\mathrm{z}$ zakresu historii wychowania. Habilitował się $\mathrm{w}$ roku 1972, w 1991 r. uzyskał tytuł profesora zwyczajnego. Od wielu lat prowadzi zajęcia z za-

\footnotetext{
${ }^{1}$ K. Bartnicka, I. Szybiak, Zarys historii wychowania, Wydawnictwo Akademickie „Żak” i Wyższa Szkoła Humanistyczna w Pułtusku, Warszawa 2001, ss. 221.

${ }^{2}$ S. Możdżeń, Historia wychowania do 1795 roku, Sandomierz 2006, ss. 431; idem, Historia wychowania 1795-1918, Sandomierz 2006, ss. 397; Historia wychowania 1918-1945, Sandomierz 2006, ss. 275.

${ }^{3}$ Historia wychowania. Skrypt dla studentów pedagogiki, pod red. D. Dryndy, Wydawnictwo Wyższej Szkoły Pedagogicznej TWP, Warszawa 2006, ss. 234.
} 
kresu historii wychowania, początkowo na UMCS (lata 1955-1962 i 1969-1984), później w latach 1962-1968 w Pracowni Dziejów Oświaty Polskiej Akademii Nauk, a od roku 1984 w Wyższej Szkole Pedagogiki Specjalnej im. M. Grzegorzewskiej w Warszawie. W ostatniej z wymienionych uczelni, która dziś nosi nazwę Akademii Pedagogiki Specjalnej, kierował Katedrą Podstaw Pedagogiki i Historii Wychowania ${ }^{4}$.

Autor sam przyznaje we „Wstępie”, że podręcznik powstał na bazie wykładów z zakresu historii wychowania, które prowadził dla studentów pedagogiki. Przed ukazaniem się omawianej publikacji, prof. Poznański, w celu ułatwienia pracy studentom, zamieścił także skrypt ze swoich wykładów w Internecie. Warto zaznaczyć, że Autor ma już za sobą doświadczenia z przygotowywaniem tekstów przeznaczonych do podręczników akademickich. Współuczestniczył bowiem w pracach nad: II tomem Historii wychowania pod redakcją Łukasza Kurdybachy ${ }^{5}$, I tomem Historii wychowania. Wiek XX pod red. Józefa Miąso ${ }^{6}$, a ostatnio, nad wymienionym już wcześniej, skryptem pod redakcją D. Dryndy ${ }^{7}$. Nic zatem dziwnego, że posiadając tak znaczący dorobek w tym zakresie oraz ogromne doświadczenie dydaktyczne prof. Poznański postanowił przygotować własną publikację dla studentów pedagogiki.

Prezentowany podręcznik składa się z 6 rozdziałów. Pierwszy z nich ${ }^{8}$ charakteryzuje wychowanie nowożytne poprzez pryzmat poglądów pedagogicznych takich postaci, jak Wolfgang Ratke, Jan Amos Komeński i John Locke. Po tym wstępie, Autor przeszedł do omówienia, w kolejnym rozdziale ${ }^{9}$, wychowania w Polsce na przestrzeni XVII i XVIII wieku, w którym oczywiście nie mogło zabraknąć informacji o Szkole Kadetów w Luneville, Collegium Nobilium, Szkole Rycerskiej oraz szkolnictwie pijarskim i jezuickim. Obszerny fragment podręcznika poświęcony został działalności i ocenie dorobku edukacyjnego Komisji Edukacji Narodowej (s. 42-62). Rozdział trzeci ${ }^{10}$ dotyczy nowych prądów w wychowaniu i szkolnictwie europejskim XVIII i XIX w., które pojawiły się za sprawą rewolucji francuskiej oraz takich myślicieli, jak Jan Jakub Rousseau, Jan Henryk Pestalozzi czy Jan Fryderyk Herbart.

Ze względu na zainteresowania naukowe prof. Poznańskiego ${ }^{11}$ nie dziwi fakt, że w rozdziale czwartym ${ }^{12}$, poświęconym szkole i wychowaniu na ziemiach polskich pod

\footnotetext{
${ }^{4}$ W. Szulakiewicz, Profesor Karol Klemens Poznański-historyk oświaty i wychowania, pedagog. (W siedemdziesiata piątq rocznice urodzin), „Kultura i Edukacja” 2006, nr 1-2, s. 191-196.

${ }^{5}$ Historia wychowania $t$. I-II, pod red. Ł. Kurdybachy, Warszawa 1968. Karol Poznański dla potrzeb II tomu opracował m.in. rozdziały dotyczące „Szkolnictwa i wychowania w Królestwie Polskim na początku II połowy XIX wieku” oraz „Myśli pedagogicznej Bronislawa Trentowskiego”.

${ }^{6}$ Historia wychowania. Wiek XX, T. 1, red. J. Miapso, wyd. 2, Warszawa 1981. Opracowal zagadnienia: Rozwój szkolnictwa wyższego [w latach 1918-1932]; Szkolnictwo wyższe po reformie; Wspóltworzyl teź z innymi autorami następujące podrozdziały: „Rozwój oświaty przed I wojną światową"; "Ustawa o szkołach wyższych z 15 marca 1933 roku".

${ }^{7}$ Opracował rozdział 9 tego skryptu pt. „Szkoła i wychowanie na ziemiach polskich w okresie zaborów”.

8 "Wychowanie nowożytne - epoka liberalizmu i baroku”, s. 7-23.

9 "Wychowanie nowożytne w Polsce w XVII i XVIII wieku", s. 25-62.

10 „Nowe prądy w wychowaniu i szkolnictwie europejskim na przełomie XVIII i XIX wieku”, s. 63-82.

${ }^{11}$ K. Poznański, Reforma szkolna w Królestwie Polskim w 1862 roku, Wroclaw 1968; idem, Oświata i szkolnictwo w Królestwie Polskim 1831-1869: lata zmagań i nadziei, cz. 1, Przebudowa systemu szkolnictwa $i$ wychowania $w$ Królestwie Polskim w latach 1831-1839, Warszawa 2001; idem, Oświata i szkolnic-
} 
zaborami, najszerzej omówiona została sytuacja na terenie zaboru rosyjskiego. Krótsza prezentacja dwóch pozostałych zaborów pozwala jednak uzyskać czytelnikom wystarczającą wiedzę na temat szkolnictwa i myśli pedagogicznej na obszarach znajdujących się pod kontrolą Austrii i Rosji. Prezentacji nowych koncepcji pedagogicznych przełomu XIX i XX w. (Herberta Spencera, George'a Kerschensteinera i Johna Dewey’a) poświęcony został rozdział piąty ${ }^{13}$ podręcznika. Podręcznik zamyka, przedstawione $w$ rozdziale szóstym $^{14}$, omówienie szkolnictwa i wychowania w Polsce w okresie II Rzeczypospolitej.

W najnowszej publikacji prof. Poznańskiego widoczne jest zatem dążenie do ukazywania dziejów polskiej edukacji i myśli pedagogicznej na szerszym tle europejskim, każdy $\mathrm{z}$ rozdziałów dotyczących rodzimej oświaty poprzedzony bowiem został prezentacją nowych prądów wychowawczych na świecie. Ułatwia to ukazanie recepcji poglądów najwybitniejszych przedstawicieli europejskiej i amerykańskiej myśli pedagogicznej na gruncie polskim. Niekiedy dla wyraźniejszego ich przedstawienia autor prezentuje je łącznie (jak w przypadku Ewarysta Estkowskiego i Adolfa Diesterwega). Należy też podkreślić, że rozważania o takich postaciach jak J. J. Rousseau czy J. H. Pestalozzi wzbogacają informacje o ich związkach z Polską i Polakami. Czytelnik otrzymuje też przejrzysty i niezwykle przydatny przegląd przemian religijnych, społecznych, kulturowych i naukowych zachodzących w społeczeństwach Europy na przestrzeni kilku wieków (od XVII do XX w.).

W końcu każdego z rozdziałów Autor zamieścił pytania kontrolne, które pozwalają studentom sprawdzić poziom opanowania przedstawionych treści. Prof. Poznański zadaje bowiem zróżnicowane pytania, część z nich dotyczy szczegółów faktograficznych, pozostałe wymagają od czytelnika refleksji porównawczej i oceniającej. Te ostatnie wydają się szczególnie cenne wobec niechęci części studentów do osobistego ustosunkowania się do poznawanych koncepcji oświatowo-wychowawczych. Warto zaznaczyć, że podręcznik wzbogaca dość szeroki wykaz literatury, od prac klasycznych po najnowsze, obejmujący podręczniki do historii wychowania, opracowania ogólne oraz wydawnictwa źródłowe. Publikacja zawiera także tabele odnoszące się do rozwoju poszczególnych szczebli szkolnictwa polskiego na przestrzeni XIX i XX w.

Przechodząc do podsumowania prezentacji najnowszego wydawnictwa podręcznikowego do historii wychowania należy podkreślić, że zostało ono w znacznej mierze oparte na najnowszych wynikach badań z tej dziedziny wiedzy. Olbrzymie doświadczenie dydaktyczne Autora miało zapewne duży wpływ na dobór i układ treści i w efekcie przyczyniło się do powstania interesującej publikacji. Jej czytelnicy mogą tutaj odnaleźć nie tylko opis faktów i pojęć, których znajomość jest niezbędna dla pozytywnego zaliczenia egzaminu z historii wychowania, lecz także poznać pewne mechanizmy i zależności

two..., cz. 2, Szkoły rzemieślniczo-niedzielne, Warszawa 2001; tenże, Oświata i szkolnictwo..., cz. 3, Polityka oświatowa caratu w latach 1834-1861, Warszawa 2004; Walka caratu ze szkolq polskq w Królestwie Polskim w latach 1831-1870: materiały źródlowe, wybór, wstęp i opracowanie K. Poznański, Warszawa 1993; Stan $i$ potrzeby badań nad oświata $i$ wychowaniem $w$ Królestwie Polskim w latach 1815-1915, pod red. J. Kuchy i K. Poznańskiego, Lublin 1989.

12 „Szkoła i wychowanie na ziemiach polskich pod zaborami”, s. 83-174.

13 „Pedagogika przełomu XIX i XX wieku”, s. 175-199.

14 „Szkolnictwo i wychowanie w Polsce w latach II Rzeczypospolitej”, s. 201-237. 
przyczynowo-skutkowe, tak istotne dla uzyskania szerszej perspektywy historyczno-oświatowej. Warto podkreślić także i to, że prof. Poznański nawet najtrudniejsze problemy i teksty pedagogiczne przedstawia w przystępny sposób, czemu sprzyja także język publikacji. Unikanie zdań wielokrotnie złożonych oraz wyraźne podkreślanie cech charakterystycznych omawianych koncepcji i zjawisk sprzyja ich szybszemu opanowaniu i co najważniejsze, także zrozumieniu. $Z$ pewnością podręcznik może stać się doskonałą pomocą zarówno dla wykładowców, jak i dla studentów, którzy już wcześniej docenili wysiłek Autora licznie odwiedzając strony internetowe, na których zamieścił on swoje wykłady.

Agnieszka Walęga

\section{Krzysztof Ratajczak, Edukacja kobiet w kręgu dynastii piastowskiej w śred- niowieczu, Wydawnictwo Poznańskie, Poznań 2005, s. 218}

Z serii „Poznańskie Studia Historyczne” w 2005 r. ukazała się książka Krzysztofa Ratajczaka pt: Edukacja kobiet w kręgu dynastii piastowskiej w średniowieczu. Stanowi ona istotny wkład w rozwijany aktualnie kierunek w historiografii poświęcony kwestiom kobiecym (gender studies), tym cenniejszy, że poruszający problem wychowania niewiast w dziejach Polski najdawniejszych. Ciekawym ponadto aspektem jest także i to, że autorem pracy jest mężczyzna... Sam Autor we „Wstępie” zaznaczył, iż zamierzeniem jego dociekań było także prześledzenie środowiska społecznego, wychowawczego, kultury dworskiej, obyczajowości, czynników wychowawczych i socjalizujących, w jakich wzrastały przedstawicielki dynastii piastowskiej, stąd śmiało można także stwierdzić, iż prezentowana praca stanowi również element szeroko pojmowanej historii kultury.

Wykorzystane przez K. Ratajczaka źródła i literatura przedmiotu zasługują na osobną uwagę. Przede wszystkim z faktu, że są bardzo różnorodne, tak gatunkowo, jak i nawet językowo. Ich dobór był podyktowany, a dotyczy to źródeł, znikomą obecnością kobiet w życiu publicznym. Tym cenniejsza zatem wydaje się próba, podjęta przez Autora, odtworzenia sposobu myślenia niewiast średniowiecznych. Także spis wykorzystanej literatury jest imponujący: znalazły się w nim bowiem opracowania genealogiczne, liczne biografie, prace dotyczące historii politycznej, gospodarczej, społecznej, kultury, wychowania, literatury, historii Kościoła i poszczególnych zakonów.

Książka K. Ratajczaka składa się z pięciu rozdziałów. Pierwszy z nich ukazuje pozycję kobiety w społeczeństwie średniowiecznym i czynniki ją warunkujące. Częścią tego rozdziału jest także analiza poglądów uczonych średniowiecznych oraz Ojców Kościoła na te kwestie. Następnie Autor przybliża czytelnikowi wizerunek dworu piastowskiego oraz jego dynastii. Czyni to głównie za sprawą opisania rodowych planów matrymonialnych, wpływów dworów obcych, życia codziennego na dworze piastowskim. W sferze zainteresowań Autora znajduje się ponadto grono osób bezpośrednio uczestniczących w procesie wychowywania i socjalizacji dzieci polskich władców. Specyficznym środo- 